Home | Publications | Calendar | Jobline | Conference | Membership |

Continuing Education | Organization | Legislative Agenda

\title{
OLA Hotline
}

Volume 13 No. 13--May 1, 2007

In this issue:

\section{ASSOCIATION NEWS}

- Message from OLA President, Aletha Bonebrake

- Election of OLA Officers

- Oregon Authors Bibliography Available!

- $\quad$ CSD Programs for OLA/WLA Joint Conference

\section{ANNUAL CONFERENCE NEWS}

- OLA Conference Materials at NW Central

- Congratulations to the OLA Award Winners!

- OYAN Celebrates Teen Service Providers with OYEA! Award

- CSD Silent Auction Winner

- Another Great Year for OYAN Raffle!

- Dateline: Karaoke 101

\section{LEGISLATIVE NEWS}

- $\quad$ Virtual National Legislative Day

\section{HAPPENINGS}

- 2007 Oregon Virtual Reference Summit

- $\quad$ BCR Teleconference - The Relevance of Libraries in a Digital Age: Library Challenges \& Opportunities

- New Library in Bethany Village

\section{EMPLOYMENT OPPORTUNITIES}

- Reference and Instructional Services Librarian, Deadline May 4, 2007

- Bilingual Youth Librarian, Deadline May 11, 2007

- Library Assistant I, Deadline May 13, 2007

- Library Clerk (2 part-time positions), Deadline May 23, 2007

- Library Technology and Catalog Librarian, Deadline 
May 31, 2007

- Manager of Library Technical Services, Deadline June 4, 2007

- Library Technician 3, Open Until Filled

- Music Librarian, Open Until Filled

- Digital Projects and Catalog Management Librarian, Open Until Filled

- Secondary Research Analyst, Open Until Filled

- Reference and Distance Services Librarian, Open Until Filled

- Library Technican 3, Open Until Filled

- $\quad$ Library Director (Veneta), Open Until Filled

- $\quad$ BTS Business Analyst, Open Until Filled

- Library Executive Assistant, Open Until Filled

- Assistant University Librarian - Public Services, Open Until Filled

- Business \& Economics Reference \& Instruction Librarian, Open Until Filled

- Library Director (Lakeview), Open Until Filled

\section{CALENDAR}

\section{Association News}

\section{Message from OLA President, Aletha Bonebrake}

We are coming up on a critical May 15 election that will determine the future of the Jackson County Library. This wonderful library system is the largest in recent US history to be closed. The Oregon Library Association salutes the spirit of Jackson County Library staff. In support of Jackson County, the Oregon Library Association Executive Board adopted the following resolution at its Annual Conference in Corvallis. May these words inspire us all to remember why we serve and why the good fight is always worth fighting.

\section{LET IT BE KNOWN}

WHEREAS

All 15 branches of the Jackson County Library are closed

\section{WHEREAS}


Democracy depends on literate and informed citizens, and free access to libraries provides all citizens regardless of age, gender, ethnic background or economic status, the resources to become informed and knowledgeable

\section{WHEREAS}

Without public libraries young children do not receive the benefits of early literacy development through preschool story times, "Babies in the Library" programs, Summer Reading Programs, Outreach to Child Care Services, and exposure to a wide variety of age appropriate beautifully illustrated picture books

\section{WHEREAS}

Without public libraries children and teens may not develop a love of books and reading, through book talks and programs such as Storyteller at the Library and Summer Reading

\section{WHEREAS}

Without public libraries people of all ages may not experience a wide variety of books, audio books, and other library materials; access accurate and reliable information; have free access to the Internet and other electronic resources; have the assistance of experienced librarians to find accurate and reliable information; and participate in community meetings and cultural events

\section{WHEREAS}

Without public libraries homebound individuals are unable to access accurate and reliable information and meet their reading needs

\section{WHEREAS}

Jackson County Library is a model of efficient and effective library service

\section{THEREFORE}

Let it be known that the Oregon Library Association

\section{HEREBY}

Strongly urges support for Jackson County Library in its efforts to restore funding 
As an organization that is operated by elected and appointed officers, it is time for OLA to elect our leadership for 2007-08. Eight members of OLA have agreed to place their names in nomination to you, the membership. They are all qualified and dedicated to library service and you will have a tough time making a decision. The balloting will open on May 1st and close at the end of the day on May 15th. The election will take place via OLA's MemberClicks site and you will receive an email with instructions on May 1st.

Listed below is the slate of candidates. Full biographies and candidate statements will be a part of the ballot information sent on May 1st.

President Elect: Teresa Landers, Corvallis-Benton County Public Library and Mary Ginnane, Eugene Public Library

Secretary: Brandon Barnett, Multnomah County Library and Hannah Rempel, Oregon State University

Treasurer: Emily Asch, Pacific University and Shirley Roberts, Eastern Oregon University

ALA Representative: Suzanne Sager, Portland State University and Cara List, University of Oregon

We appreciate these individuals putting themselves up for election and OLA will be well served with whichever candidate receives the most votes. Questions can be directed to the OLA Nominating Committee: Leah Griffith, Mary Norman, Maureen Kelly.

\section{Oregon Authors Bibliography Available!}

Oregon Authors Bibliography 2005 is now available at the OLA website! Special features include:

- Residences of Oregon Authors

- Oregon Subject Headings

- Juvenile literature Notations

Get the latest edition of the Oregon Authors Bibliography (1933- ) for only $\$ 10.00$ ! 


\section{CSD Programs for OLA/WLA Joint Conference}

If you are interested in presenting a CSD sponsored program at the OLA/WLA joint conference in Vancouver (yes, we mean Washington!), please contact Karen Fischer by May 10th. The CSD conference committee will meet before June to decide on our submissions to the joint conference committee, which are due August 15.

\section{Annual Conference News}

\section{OLA Conference Materials at NW Central}

NW Central, which is a centralized continuing education site for the Northwest region, is the outgrowth of a PORTALS project and LSTA grant. The project is fully sanctioned by OLA, which recently voted to create a new OLA board position which will act as liaison to NWCentral. OLA intends that this site become the forum for all OLA continuing education activities.

Conference presenters can add their material to NW Central. To add content, simply create a free account by choosing 'login/register' on the left hand side of the page, then 'add content' under the 'add and find resources' tab. This is also a way that you can communicate with your attendees, if you wish.

To view content, choose the 'By Resource Type' link on the left hand menu and then choose one of the options listed under that link (i.e., handout or presentation).

\section{Congratulations to the OLA Award Winners!}

The Oregon Library Association (OLA) honored the following library employees and supporters at its annual conference in Corvallis during the week of April 18. These individuals were chosen for demonstrated excellence in library service in Oregon.

HONORARY LIFETIME AWARD

Ronnie Budge, 2004 Librarian of the year, was awarded the 
Honorary Lifetime Award for Excellence in Library Services. She devoted over 33 years to library work and spent the past 20 years in the Jackson County Library. Her community partnerships and creative programs provided many opportunities for efficient innovations. She retired in February. She is now volunteering with other community leaders to facilitate the opening of the recently closed Jackson County Library.

\section{OREGON LIBRARIAN OF THE YEAR \& OLÉ AWARD}

Teresa Landers, Deputy Library Director of the CorvallisBenton County Public Library, was named Oregon Librarian of the Year. Her inspiring results have had a positive impact on many communities and she is recognized as a local, regional, and national leader in library services. Teresa also won the OLÉ Award. This award is given to a person who has displayed exceptional effort and is so named in recognition of the recipient's efforts to "take the bull by the horns" to get a job done.

\section{EMPLOYEE OF THE YEAR}

Marcia Poehler, Adult Services Senior Assistant in the Salem Public Library, received the Employee of the Year Award. Marcia has been described as the "heart" of Adult Services at Salem Public Library. Nominators said she is able to combine an uncanny, pro-active sense of what needs to be done in the larger picture of work management in Adult Services, with a gracious and engaging manner for encouraging staff to collaborate on problem-solving. She also celebrates 20 years of dedication in 2007 !

\section{EVELYN SIBLEY LAMPMAN AWARD}

Carol Reich, Youth Services Manager, Hillsboro Public Library, was awarded the Lampman Award. She has demonstrated leadership by inspiring generations of children to grow up to be readers, and collaborated with many partners, such as the Harkins House Juvenile Shelter and the Virginia Garcia Memorial Health Center to improve access to books and encourage reading by children and teens in her community. State Librarian Jim Scheppke notes that Reich "oversees a vibrant, active youth services department in Hillsboro which has been innovative and creative in programming and services." For nearly 20 years, Carol Reich has served as a role model for library staff who wants to make an impact on children's literacy and library use. 
The Lampman Award is Oregon's most notable and prestigious award for library service to children. It was established in 1982 to honor a living Oregon author, librarian, or educator who has made a significant contribution to Oregon in the fields of children's literature and library services. The award is given in memory of Evelyn Sibley Lampman (19071980), noted Oregon teacher, journalist, and author of children's books.

LIBRARY SUPPORTERS OF THE YEAR (2 Awards) The Library Supporter of the Year had two winners. Freda Vars, of the Corvallis-Benton County Public Library, was recognized for her long- time volunteer service, as well as for her years as a State Library Board member. Reading Education Assistance Dogs (R.E.A.D) Teams (handler and dog) throughout Oregon received the same award. These dedicated teams travel to different library branches after school or on weekends helping young readers.

\section{OLA PRESIDENT'S AWARD}

The OLA President's Award was given to Camila Gabaldón, Collection Development Librarian/Assistant Professor, Western Oregon University.

\section{OYAN Celebrates Teen Service Providers with OYEA! Award from April Witteveen}

The Oregon Young Adult Network has wanted to give out an award for a couple of years. We've known about amazing work being done for teens in libraries throughout the state, and this year we got our chance to work out the process and make the OYEA! Award a reality. What does OYEA stand for, you ask? It's "OYAN's You're Excellent Award!" This year's award was presented on the Wednesday evening of the OLA Annual Conference. We had an excited and enthusiastic audience!

The Award Committee was very excited to receive nine fantastic nominations, some for librarians who have revolutionized the way their library serves teens, and some for projects that brought new partnerships and programming to libraries. All nominees received a certificate of appreciation. If you are interested in seeing the full list of nominees and their accomplishments, please contact Susan Ludington, this year's 
OYEA! Award Committee Chair.

Drum roll, please! The winners of this new award are Andrew Cherbas and Heidi Weisel of Corvallis-Benton County Public Library. They received an engraved plaque and also a $\$ 100$ cash award to further their work with teens. Nominated by Teresa Landers, Deputy Library Director at CBCPL, these two librarians "respond[ed] to an identified community need" to provide more programs and material collections to area teens. Their incredible successes are an inspiration to think creatively about what our libraries offer teens. Congratulations to Andrew and Heidi, and OYAN looks forward to next year's award!

\section{CSD Silent Auction Winner}

Congratulations to Nancy Spaulding of Cedar Mills Public Library, winner of the original artwork from the 2002 Summer Reading Program, "Don't Bug Me, I'm Reading." Bidding took place during the OLA Conference at the CSD table. Nancy's winning bid of $\$ 220$ purchased this wonderful framed artwork.

\section{Another Great Year for OYAN Raffle!}

The Oregon Young Adult Network again conducted its annual raffle fundraiser at this year's OLA Annual Conference in Corvallis. With a variety of great prizes, including the everenticing two-night stay at the Sylvia Beach Hotel, we sold over \$1700 in tickets. Lee-Anne Flandreau was the lucky winner of the Sylvia Beach Hotel prize.

OYAN thanks everyone who made a ticket purchase, whether for one or ten tickets. The money raised by the raffle goes toward several of OYAN's projects, including a continuing education/professional development scholarship fund for members, bringing speakers to OYAN- sponsored programs, running workshops and trainings, etc. Be on the lookout for OYAN members with YA stickers at the joint conference next year!

\section{Dateline: Karaoke 101 from Maureen Cole}

For those of you who attended the Past President's Reception 
event, Karaoke 101, you now know that the PPRT will do almost anything to make a buck for the OLA MLS

Scholarship Fund. That includes rockin' \& rollin', shaking some booty, bidding on temporary tattoos, and joining in group sing alongs. Led by incomparable Eugene comedienne Leigh Anne Jasheway-Bryant, fifty or so people let out their inner "American Idol" for almost 2 hours. In the process, over $\$ 600$ was raised, which will be matched, up to $\$ 1000$, by the PPRT. And the money continues to roll in from those people who could not attend.

If you would like to contribute to this wonderfully worthy cause, please make your check to Oregon Library Association MLS Scholarship Fund, and mail to:

Oregon Library Association

P.O. Box 2042

Salem, OR 97308-2042

Thank you everyone for all donations to date and for those who could attend, thank you for contributing to a very fun, unforgettable night. I don't think we have shown up on You Tube yet!

\section{Legislative News}

Virtuall National Legislative Day from Janet Webster

As several of us head back to Washington, D.C. for National Legislative Day on May 2, we hope many of you will call your Representatives and Senators. It's simple! Go to the ALA Legislative page to find the phone number, call, and tell the person who answers that you hope your representative and senator will support full funding of LSTA. Of course, you can address other issues - DOPA, copyright, privacy, etc. And, you can send an email if you are nervous about making the call. A tip - cover one issue per email. The ALA Washington Office has background on the various issues.

The OLA Legislative Committee has created an issue brief on social networking that gives examples of how we are using social networking. You could fax this with a cover letter. The important thing is to make some contact. Those of us who will be there would love to walk in to Senator Smith's or Wyden's 
office and have them comment about the number of calls they've received. So mark May 2 as the day to call Washington.

Thanks for speaking up. ---OLA Legislation Committee

\section{Happenings}

\section{Oregon Virtual Reference Summit}

The 2007 Oregon Virtual Reference Summit is a free, one-day conference that seeks to help virtual reference practitioners in Oregon meet and learn from one another. A full program can be viewed at: .

The Summit will be held on June 1 from 9:30am-4:30pm at Central Oregon Community College Library, Bend, OR. Register online at the conference website. Registration is free and priority will be given to staff in Oregon libraries that register by May 1 . Many attendees are partners with L-net but the summit is open to all.

Plenary speaker Marie Radford is Associate Professor \& Library Consultant at the School of Communication, Information \& Library Studies at Rutgers University. She is co-principal investigator for Seeking Synchronicity: Evaluating Virtual Reference Services from User, Non-User, and Librarian Perspectives and an expert on interpersonal relationships in virtual reference.

Other programs include:

- Keeping up with the best online web resources - Amy Lee and Sam Wallin, Fort Vancouver Regional Library

- What students need, what schools need - a panel discussion about teen use of L-net, Oregon's statewide virtual reference service

- Best practices in Virtual reference

- Mary Ross, formerly of Seattle Public Library

BCR Teleconference - The Relevance of Libraries in a Digital Age: Library Challenges \& Opportunities 
This teleconference is free to library staff in Oregon libraries and will be broadcast on Friday, May 11, from 9am 10:30am.

James G. Neal, the Vice President for Information Services and University Librarian at Columbia University, will assemble a panel to discuss the future relevance of libraries as we know them. The digital age has been with us long enough to make some practical predictions of how traditional roles of libraries will change in information selection, acquisition, synthesis, navigation, dissemination, interpretation and archiving. New responsibilities in information aggregation, publishing education, research and development and policy advocacy will be explored. It promises to be a lively and provocative session. The full webcast description has additional information.

This teleconference is part of the "Library Challenges \& Opportunities" series of workshops brought to you by the Oregon State Library and BCR and funded by LSTA. A DVD of this and previous workshops will be made available through interlibrary loan soon. Check OSL's BCR Teleconference webpage for updates.

View the training via webcast from your personal computer or a computer you can access easily. Or you may attend a group session at a location near you. Please review the host sites to find a convenient location.

Register for the webcast online. Or register for a group session at a location near you. Select the site you want and, using the contact information provided, register by email or phone to attend that group session.

\section{New Library in Bethany Village}

The Cedar Mill Community Library signed a lease to rent a storefront to establish and operate a library in Bethany Village beginning this summer. Bethany is a fast growing area in unincorporated Washington County that will add up to 10,000 new residents in the next 10 years. The new library will be open 7 days a week and will focus on providing popular materials for all ages with a strong emphasis on materials and services for young children. The library is currently recruiting 
for staff, including a full time branch librarian and a full time branch library assistant to work at this branch. See more details about the openings and the library at the Cedar Mill website.

\section{Employment Opportunities}

Calendar 